\title{
New Career Development Strategies: Methods and Resources
}

\author{
Juliet V. Miller and Libby Benjamin
}

A comprehensive view of career development dictates a review, an evaluation, and an expansion of strategies used in career guidance programs. Several forces underlie this need: (a) the expanded age range of the population served, which now stretches from preschool to postretirement; (b) the unique needs of special populations; (c) the radical change in life styles and goals in today's culture; (d) the ever-increasing numbers of individuals making major occupational changes, even at midlife; (e) the dramatic change in learning settings as career development concepts are becoming infused into all areas of the curriculum; and ( $f$ ) the trend toward accountability for whatever methods are chosen to achieve educational goals.

The selection of methods and resources for a career guidance program must be preceded by a number of program planning steps. Several recent writers (Cook 1972; Jones et al. 1972; O'Hare \& Lasser 1971) have suggested the advantages of using a comprehensive systems approach for developing career guidance programs. This approach involves a number of steps, which ultimately result in career guidance pro-

Juliet V. Miller is Assistant Director of Measurements and Guidance in the Oakland Schools in Pontiac, Michigan. Libby Benjamin is Associate Director for User Services in the ERIC Counseling and Personnel Services Information Center at the University of Michigan in Ann Arbor. grams that are tailored to the needs of the individuals whom the program serves. Basically, this approach includes four steps: needs assessment, development of goals and objectives, identification and selection of guidance strategies (methods and resources), and program evaluation.

The systems approach assumes that effective program development includes the use of all four steps. This means that needs assessment (the identification and prioritizing of individual needs) and the development of program goals and objectives must precede the selection of guidance strategies and that program evaluation must follow such selection so that information about the effectiveness and efficiency of the strategies can be used in subsequent program revision.

\section{QUESTIONS TO ASK ABOUT STRATEGIES}

Several key questions should be explored as potential guidance strategies are being reviewed.

What is the learning potential? Once guidance objectives have been developed, information about various strategies should be analyzed to assess their effectiveness in facilitating the types of outcome behaviors desired. Sources of this information might be journal articles, published reports, discussions with others who have used the methods, and method reviews (Budke 1971; Campbell \& Vetter 1971; Campbell et al. 1973; Hansen 1970; Miller \& Leonard 1974; Walz 1972). 
How appropriate is the strategy? Specific strategies and resources are often designed for use with individuals who are at a particular developmental level (e.g., elementary students) or who have particular characteristics (e.g., disadvantaged students). When selecting strategies, such individual characteristics as educational level, ability, achievement, educational and occupational aspiration, sex, ethnic membership, self-concept, and motivation should be considered.

What is the expertise of available staff? Another critical factor to consider in selecting strategies is staff competencies. All other factors being equal, a strategy should be selected either because someone on the existing staff has, or can acquire through training, the requisite expertise or because other resource people are available.

What program resources are available? Guidance strategies require specific facilities, equipment, and materials that often are quite costly. Therefore, methods should be selected only if they can be implemented with existing resources or with obtainable resources.

What impact will the strategy have on the existing program? The selection of new guidance strategies represents a change effort. Because change in one part of a program usually requires subsequent changes in other parts of the program, change is often difficult to initiate and maintain. In selecting a guidance strategy, it is important to consider its impact on other parts of the program. In general, it is preferable to select those strategies that either will require only minimal change or will be compatible with the existing program.

\section{STRATEGIES FOR LIFE CAREER DEVELOPMENT}

Below are described a selected group of career guidance strategies that seem to hold promise for facilitating the guidance outcomes defined by the new life career development concepts. Each description includes an overview of the strategy, possible broad career guidance outcomes that the strategy might facilitate, and references to further information.

Achievement Motivation Training. This strategy consists of a number of procedures designed to increase individuals' motivation to achieve success by helping them function more independently and efficiently. Such programs involve these tasks: (a) teaching individuals the characteristics of high achievers, (b) teaching strategies that could lead to high achievement, (c) helping individuals set both short- and long-term goals, and (d) providing support for achieving selfdetermined goals. This strategy can lead to the fulfillment of career guidance goals related to self-development and career planning. Increased motivation to achieve helps individuals feel more positive about themselves and helps them develop effective goal setting behaviors (Alschuler 1969; Carlson 1972; Kopita 1973; McClelland 1968).

Assessment Techniques. Assessment techniques include standardized tests and other measurement techniques that are designed to measure specific individual characteristics. Traditionally, career guidance has relied heavily on norm-referenced testing to provide information about self for use in career planning. Recently developed criterionreferenced tests are designed to measure an individual's performance in relation to specific program objectives by reporting the number of objectives achieved and the nature of errors made on objectives not achieved (Harsh 1974; Jones et al. 1972). A number of available career planning programs combine normreferenced achievement and ability data with information about an individual's values, interests, and career plans. These programs use extensive reporting formats that provide both the individual and the counselor with an array of in- 
formation appropriate for use in career planning (American College Testing Program 1972; College Entrance Examination Board 1971; Prediger 1973; Psychological Corporation 1973; Science Research Associates 1968). In helping individuals understand their own personal characteristics, assessment data relate to self-development objectives. In addition, as career planning programs help individuals relate selfinformation to career options, assessment data also lend support to career planning objectives.

Career Resource or Learning Centers. The availability of career resources, physical facilities, equipment, and adequate staffing remains a prerequisite for the development and effective implementation of a variety of career guidance strategies. The concept of the career resource center recently has been expanded to include the availability of comprehensive resources; physical space for the use of those resources with clients on a group or individual basis; differentiated staffing, including volunteers, paraprofessionals, learning resource specialists, and counselors; and outreach services to facilitate the use of resources in settings other than the center. The most sophisticated career resource centers include comprehensive information systems for storage and retrieval of information, curriculum linkages, and carefully designed career guidance experiences to help individuals use the resources effectively (Alameda County School Department 1972; Circle et al. 1968; Hansen 1971; Indiana Career Resource Center 1971; Loheyde 1972; Minnesota State Department of Education 1972; Moore 1972; O'Neill 1972; Peterson et al. 1974; Willingham et al. 1972).

Career Development Curriculum. Because they provide career development experiences for a large number of persons, the existing school curriculum and the classroom setting can be used efficiently for implementing career guid- ance. It is important to consider three factors in using the curriculum model. First, new curriculum materials must be developed to deal with the life career development concepts. Second, individualization is needed so that individuals can explore information that is personally relevant. Finally, teachers must be trained to be effective in relating to individuals and in structuring the classroom situation so that exploration may occur. Infusion of career development concepts into the curriculum can be helpful in facilitating self-awareness and career awareness and in developing career planning behaviors. Counselors should have an active role in curriculum development and implementation and should help individuals apply classroom learnings to their personal career planning through ongoing guidance services (Adkins 1970; Benson 1972; Birk \& Tanney 1973; Carr et al. 1972; Cunha 1972; Human Development Services 1974; Minnesota State Department of Education 1972; Oregon State Department of Education 1968; Talbot et al. 1972; Vetter \& Sethney 1972).

Decision-Making Training. Current theories of career development stress the importance of decision making, and a number of programs have been developed to teach decision making through the use of either the computer or the curriculum. These programs emphasize the exploration and clarification of personal values, the study of the decision-making process, and the use of data about self and environment. Such programs also provide opportunities for individuals to acquire and use decision-making skills in simulated or real-life situations. Decision-making training programs enhance selfdevelopment by helping individuals identify personal values and relate them to future career options. The major outcome of these programs is the development of skills in planning and decision making, which can be used to cope effec- 
tively throughout life (Arutunian 1973; Chapman et al. 1973; Friel 1972; Gelatt 1968; Gelatt et al. 1972, 1973; MacKenzie \& Manuel 1971; Smith 1973).

Media. Career guidance typically makes use of various forms of media (written, audio, audiovisual, computer, and simulated experience) to communicate information to individuals. The more traditional uses of media consist of such prepackaged materials as occupational information kits, films, or filmstrips. The media approach, although often useful, has some potential dangers. First, it is difficult to individualize the materials to varying levels of vocabulary, reading, and motivation. Second, media of this type provide oneway communication, which does not allow the individual an opportunity to seek interpretation and clarification of the information. Simulated experiences provide individuals with the opportunity to participate in situations paralleling real-life situations by allowing them to try out various behaviors and career planning options. Simulations, developed in such areas as career decision making, work behaviors, and attitudes and occupational problem solving, appear to be highly motivational. Two media approaches are the use of student-produced materials and the use of media for feedback. Client-produced media have the advantage of allowing those who are producing the materials to explore in depth those occupations of particular interest to them. Often the results are more interesting and relevant to other individuals than are materials produced by experts. Using media for feedback to individuals enables them to practice career-related behaviors and revise these behaviors based on the feedback. Media can be effective in promoting career awareness, particularly when they are used for feedback to enhance selfdevelopment (Bertcher et al. 1971; Boocock 1967; Ganschow et al. 1970; Jones \& Krumboltz 1970; Kagan 1970;
Krumboltz 1970; Nelson \& Krumboltz 1970; Varenhorst 1968).

Value Clarification. Value clarification is a process that includes a number of steps, such as defining values, introducing a range of values, emphasizing the impact of values on actions and decisions, and helping individuals identify their personal values. Value clarification can be used effectively with large groups, small groups, or individuals. Specific techniques include the use of role play, media, conflict situations, games, interviews, problem situations, values questionnaires, weekly reaction sheets, and time diaries. Value clarification most directly affects self-development; however, the value clarification process is essential to career planning and decision making (Carkhuff 1972; Chapman et al. 1973); Gelatt et al. 1972, 1973; Hawaii State Department of Education 1971; Raths \& Simon 1966; Simon et al. 1971).

\section{CONCLUSION}

Effective implementation of life career development concepts depends on expanded goals for career guidance. As goals expand, it is necessary to carefully evaluate guidance strategies currently in use and to seek new strategies. Use of a systematic approach to program development can insure feedback regarding the effectiveness of strategies and help prioritize areas in which new strategies are needed. Further exploration of the program descriptions found in the reference list can help in the process of selecting strategies that are particularly appropriate for local career guidance program goals.

\section{REFERENCES 1}

Adkins, W. R. Life skills: Structured counseling for the disadvantaged. Personnel and Guidance Journal, $1970,49(2), 108-116$.

'ED numbers indicate that the reference is available through the Educational Resources information Center (ERIC). 
Alameda County School Department. Guidelines for the establishment of career information centers. Alameda, Calif.: Author, 1972. (ED 074 239)

Alschuler, A. How to develop achievement motivation: A course manual for teachers. Interim report. Cambridge, Mass.: Achievement Motivation Development Project, 1969. (ED 029 967)

American College Testing Program. Handbook for the ACT career planning program. Iowa City: Author, 1972.

Arutunian, C. Case studies in practical career guidance: Number 2. Palo Alto, Calif.: American Institutes for Research, 1973. (ED 076 928)

Benson, A. A resource guide for career development in the junior high school. St. Paul: Minnesota State Department of Education, 1972. (ED 067 469)

Bertcher, H., et al. Role modeling and role playing: $A$ manual for vocational development and employment agencies. Ann Arbor, Mich.: Manpower Science Services, 1971. (ED 053 350)

Birk, J., \& Tanney, M. Career exploration for high school women: A model. Paper presented at the American Personnel and Guidance Association Convention, Atlanta, Georgia, May 1973. (E.D 079 662)

Boocock, S. S. The life career game. Personnel and Guidance Journal, 1967, 46(4), 328.

Budke, W. E. Review and synthesis of information on occupational exploration. Columbus, Ohio: ERIC Clearinghouse on Vocational and Technical Education. Ohio State University, 1971. (ED 056 165)

Campbell, R., \& Vetter, L. Career guidance: An overview of alternative approaches. Columbus, Ohio: Ohio State University, Center for Vocational and Technical Education, 1971. (ED 057 183)

Campbell, R.; Walz, G.; Miller, J.; \& Kriger, S. Career guidance: A handbook of methods. Columbus, Ohio: Ohio State University, Center for Vocational and Technical Education, 1973.

Carkhuff, R. The art of problem solving. Amherst, Mass.: Human Resource Development Press, 1972.

Carlson, R. Building a psychological career awareness model: A field study to evaluate the effectiveness of achievement motivation simulation on career development. Washington, D.C.: District of Columbia Public Schools, 1972. (ED 068712 )

Carr, R., et al. Project women in a man's world of work: $A$ guide for school counselors. Bangor, Me.: Hermon School Department, School Union \#34, 1972. (ED 074 216)

Chapman, W., et al.SIGI: Report of a pilot study under field conditions. Princeton, N.J.: Educational Testing Service, 1973. (ED 084 887)

Circle, D. F., et al. The career information service: $A$ guide to its development and use. Newton, Mass.: Newton Public Schools, 1968. (ED 021 300)
College Entrance Examination Board. Comparative guidance and placement program. New York: Author, 1971.

Cook, D. A systems approach to the development of pupil personnel services: An operating manual. Boston: Northeastern University, 1972. (ED 074 419)

Cunha, J. E. Career development: A California model for career guidance curriculum $K$-adult. California Personnel and Guidance Association Monograph No. 5. Sacramento: California State Department of Education, 1972. (ED 075 672)

Friel, T. The counselor guide to career decision-making skills. Flint, Mich.: Genesee Intermediate School District, 1972. (ED 084 432)

Ganschow, L. H., et al. Stimulating educational information-seeking and changes in student attitude toward vocational education by videotape and film presentations. Final report. Palo Alto, Calif.: American Institutes for Research, 1970. (ED 043 778)

Gelatt, H. B. A decision-making approach to guidance. NASSP Bulletin, 1968, 52(324), 88-98.

Gelatt, H. B.; Varenhorst, B.; \& Carey, R.Deciding: $A$ decision-making program for students. New York: College Entrance Examination Board, 1972.

Gelatt, H. B.; Varenhorst, B.; Carey, R.; \& Miller, G. Decisions and outcomes. New York: College Entrance Examination Board, 1973.

Hansen, L. S. Career guidance practices in school and community. Washington, D.C.: National Vocational Guidance Association, 1970.

Hansen, L. S. Promoting student career development through utilizing volunteers in a career resource center. Progress report. Minneapolis: University of Minnesota, 1971.

Harsh, J. R. The forest, trees, branches and leaves, revisited-Norm, domain, objective and criterionreferenced assessments for educational assessment and evaluation. Washington, D.C.: Association for Measurement and Evaluation in Guidance, 1974.

Hawaii State Department of Education. American values, social studies, secondary education. Honolulu: Author, 1971. (ED 056 918)

Human Development Services, Inc. Life career development system. Ann Arbor, Mich.: Author, 1974.

Indiana Career Resource Center. Resources for career development. South Bend: University of Indiana, 1971. (ED 079621 )

Jones, B., et al. Planning, developing and field testing career guidance programs: A manual and a report. Palo Alto, Calif:: American Institutes for Research, 1972. (ED 064 663)

Jones, G. B., \& Krumboltz, J. D. Stimulating vocational exploration through film-mediated problems. Journal of Counseling Psychology, 1970, 17(2), 107-114. 
Kagan, N. Multimedia in guidance and counseling. Personnel and Guidance Journal, 1970, 49(3), $197-$ 203.

Kopita, R. Searchlight: Relevant resources on counseling for achievement motivation. Ann Arbor, Mich.: ERIC Clearinghouse for Counseling and Personnel Services, 1973. (ED 082 108)

Krumboltz, J. Job experience kits. Chicago: Science Research Associates, 1970.

Loheyde, K. Annotated bibliography of career-relevant literature at the junior and senior high school level. Albany: New York State Education Department, 1972. (ED 076 830)

Mackenzie, J., \& Manuel, P. Career development and planning. Paper presented at the Ontario School Counselor Association Convention, Sudbury, Ontario, 1971. (ED 073 400)

McClelland, D. C. Achievement motivation training for potential high school dropouts. Achievement Motivation Development Project, Working paper No. 4. Cambridge, Mass.: Harvard University, 1968. (ED 029 067)

Miller, J., \& Leonard, G. Career guidance practices for disadvantaged youth. Washington, D.C.: National Vocational Guidance Association, 1974.

Minnesota State Department of Education. Career education resource guide. Minneapolis: Author, 1972.

Moore, A. Abstracts of instructional materials for career education. Columbus, Ohio: Ohio State University, Center for Vocational and Technical Education, 1972. (ED 068 627)

Nelson, D. E., \& Krumboltz, J. D. Encouraging career exploration through "simulated work" and "vocational detective" experiences. Journal of Employment Counseling, 1970, 7(2), 58-64.

O'Hare, R., \& Lasser, B. Evaluating pupil personnel programs. Monograph No. 2. Fullerton, Calif.: California Personnel and Guidance Association, 1971.

O'Neill, V. J. Resource manual for career development for students, teachers, and counselors in the Chicago prublic schools. Chicago: Chicago Public Schools, 1972. (ED 079 556)
Oregon State Department of Education. Teacher's guide to self understanding through occupational exploration. Salem: Author, 1968. (ED 024 965)

Peterson, M., et al. Bibliography of $K-6$ career education materials for the enrichment of teacher and counselor competencies. Charleston, Ill.: Eastern Illinois University, 1974. (ED 073 287)

Prediger, D. The vital role of testing in career guidance. Paper presented at the American Personnel and Guidance Association Convention, San Diego, February 1973. (ED 078 051)

Psychological Corporation. Differential aptitude tests: Career planning report. New York: Author, 1973.

Raths, L., \& Simon, S. Values and teaching. Columbus, Ohio: Charles E. Merrill, 1966.

Science Research Associates. Vocational planning inventory. Chicago: Author, 1968.

Simon, S.; Howe, L.; \& Kirschenbaum, H. Values clarification. New York: Hart, 1971.

Smith, R. Facilitating career development through decision-making: $\boldsymbol{A}$ pilot study. Charleston, W. Va.; Appalachia Educational Laboratory, 1973. (ED 079 663)

Talbot, W., et al. Utah model for career guidance $K-12$. Salt Lake City: Utah State Board of Education, 1972. (ED 079 516)

Varenhorst, B. B. Innovative tool for group counseling: The life career game. School Counselor, 1968, $15(5), 357-362$.

Vetter, L., \& Sethney, B. Women in the work force: Development and field testing of curriculum materials. Final report. Columbus, Ohio: Ohio State University, Center for Vocational and Technical Education, 1972. (ED 072 175)

Walz, G. Information analysis and targeted communication program for improving the quality and expanding the amount of occupational exploration and career planning. Final report. Ann Arbor, Mich.: University of Michigan, 1972.

Willingham, W.; Ferrin, B.; \& Begle, E. Career guidance in secondary education. New York: College Entrance Examination Board, 1972. (ED 070011 ) 